\title{
DEAFNESS IN CHILDREN
}

\author{
BY \\ BASIL WOLMAN \\ From Bury and Rochdale Hospitals
}

(RECEIVED FOR PUBLICATION JANUARY 28, 1963)

In view of the importance of detecting deafness in children as early as possible, a special clinic was established for this purpose.

\section{Method}

Children at risk, such as those who have suffered from neonatal jaundice or meningitis, premature infants, children who have received prolonged streptomycin therapy and those in whom some retardation in mental or speech development was suspected were tested throughout 1958 to 1961 .

\section{Results}

In all, 241 children were tested and classified.

Premature Infants. Of the children tested, 88 were premature (Table 1). Of the 14 babies under $3 \cdot 5 \mathrm{lb}$. (1,580 g.), nine had started talking at about 1 year of age, whereas three did not start using single words until 2 to $2 \frac{1}{2}$ years; all passed their tests satisfactorily.

Two infants, whose birth weights were $1 \mathrm{lb} .15 \mathrm{oz}$. $(878 \mathrm{~g}$.) and $2 \mathrm{lb}$. (906 g.) respectively and who did not start talking until 2 years old, failed to pass the screening test at 1 year. When retested six months later, the first one with the lower birth weight was found to be severely deaf and the other had normal hearing.

TABLE 1

\begin{tabular}{|c|c|c|}
\hline Birth Weight & No. Tested & No. Deaf \\
\hline $\begin{array}{l}<3 \frac{1}{2} \text { lb. }(1,580 \text { g. }) \\
3 \frac{1}{2}-4 \text { lb. } 15 \text { oz. }(1,580-2,230 \text { g. })\end{array}$ & $\begin{array}{l}14 \\
54 \\
20\end{array}$ & $\begin{array}{l}1 \\
0 \\
0\end{array}$ \\
\hline
\end{tabular}

TABLE 2

\begin{tabular}{c|c|c|c|c}
\hline Year & $\begin{array}{c}\text { No. Treated } \\
\text { and Survived }\end{array}$ & $\begin{array}{c}\text { One Exchange } \\
\text { Transfusion }\end{array}$ & $\begin{array}{c}\text { More than } \\
\text { One Exchange }\end{array}$ & $\begin{array}{c}\text { No. } \\
\text { Deaf }\end{array}$ \\
\cline { 2 - 4 } & 20 & 10 & 10 & 1 \\
1958 & 10 & 8 & 2 & 0 \\
1959 & 11 & 9 & 2 & 0 \\
1960 & 21 & 19 & 2 & 0 \\
\hline
\end{tabular}

A further 54 children with birth weights between $3 \frac{1}{2}$ and $4 \mathrm{lb} .15 \mathrm{oz}$. (1,580-2,230 g.) and 20 babies over $5 \mathrm{lb} .(2,260 \mathrm{~g}$.) were tested and all were found to have normal hearing.

Haemolytic Disease of the Newborn-64 Cases. In the present series, 64 children who have been treated at birth with one or more exchange transfusions for haemolytic disease and who survived were tested, and only one child was found to be deaf (Table 2). The serum bilirubin had varied in the series from $4 \mathrm{mg}$. $/ 100 \mathrm{ml}$. to $35 \mathrm{mg} . / 100 \mathrm{ml}$. In fact, one child whose serum bilirubin reached $32 \mathrm{mg} . / 100 \mathrm{ml}$. required two exchanges and another child whose serum bilirubin reached $35 \mathrm{mg}$. $/ 100 \mathrm{ml}$., and required three exchanges, had no trouble with hearing when tested. In addition, one other child whose serum bilirubin reached $20 \mathrm{mg}$. $/ 100 \mathrm{ml}$. and for various reasons was not exchanged, did not develop kernikterus and also was not deaf.

The child who showed deafness was the second of twins, the first being stillborn and macerated. He had severe haemolytic disease necessitating three exchange transfusions at birth. The highest serum bilirubin was $12 \mathrm{mg} . / 100 \mathrm{ml}$. He shows no evidence of any nervous system disease but is undoubtedly deaf.

Meningitis-61 Cases. In these 61 children, only one was found to be deaf (Table 3). This child had meningococcal meningitis at the age of 3 months

TABLE 3

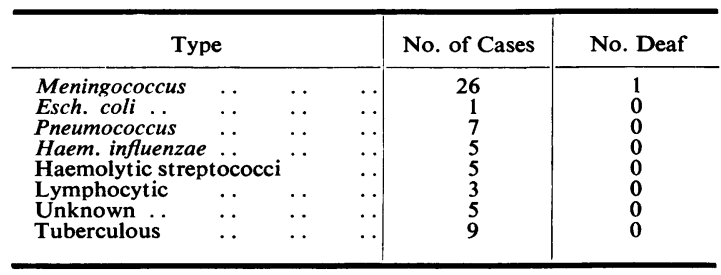


TABLE 4

\begin{tabular}{|c|c|c|c|}
\hline Name & $\underset{\text { (years) }}{\text { Age }}$ & Reason for Referring & Findings \\
\hline I.C. & 5 & Slow development of & Not deaf \\
\hline S.W. & 6 & ? Deaf & $\begin{array}{l}\text { Bilateral conductive } \\
\text { deafness }\end{array}$ \\
\hline A.W. & 6 & ? Deaf & $\begin{array}{l}\text { Bilateral conductive } \\
\text { deafness }\end{array}$ \\
\hline S.K. & 3 & $\begin{array}{l}\text { Mother deaf, child } \\
\text { suspected to be } \\
\text { deaf }\end{array}$ & $\begin{array}{l}\text { Severe deafness- } \\
\text { needing hearing } \\
\text { aid }\end{array}$ \\
\hline $\begin{array}{l}\text { A.S. } \\
\text { S.B. }\end{array}$ & $\begin{array}{l}4 \\
4\end{array}$ & $\begin{array}{l}\text { ? Deaf } \\
\text { ? Deaf }\end{array}$ & $\begin{array}{l}\text { Not deaf } \\
\text { Otorrhoea; conduc- } \\
\text { tive deafness }\end{array}$ \\
\hline A.G. & 5 & ? Deaf & $\begin{array}{l}\text { Otorrhoea; conduc- } \\
\text { tive deafness }\end{array}$ \\
\hline B.O'S. & 3 & Slow speech & $\begin{array}{l}\text { Mental defective; } \\
\text { toxoplasmosis; } \\
\text { not deaf }\end{array}$ \\
\hline $\begin{array}{l}\text { C.B. } \\
\text { L.J. }\end{array}$ & $\begin{array}{l}5 \\
5\end{array}$ & $\begin{array}{l}\text { Slow speech } \\
\text { ? Deaf }\end{array}$ & $\begin{array}{l}\text { Psychiatric case } \\
\text { Otorrhoea; conduc- } \\
\text { tive deafness }\end{array}$ \\
\hline $\begin{array}{l}\text { L.M. } \\
\text { C.L. } \\
\text { I.G. } \\
\text { M.M. }\end{array}$ & $\begin{array}{l}8 \\
3 \\
4 \\
5\end{array}$ & $\begin{array}{l}\text { ? Deaf } \\
\text { Speech difficulty } \\
\text { Speech difficulty } \\
\text { Cleft palate repair; } \\
\text { speech difficulty }\end{array}$ & $\begin{array}{l}\text { Backward } \\
\text { Not deaf } \\
\text { Not deaf } \\
\text { Not deaf }\end{array}$ \\
\hline
\end{tabular}

but started talking normally at 1 year. He was referred to this clinic at the age of 5 because of indistinct speech. Although he was found to have impaired hearing, audiometric testing showed only slight impairment and this was found to be due to a conductive element and not a central lesion. Treatment produced considerable improvement and it was considered therefore that his temporary deafness was probably unconnected with his previous meningitis.

It appeared, therefore, that none of the children who had meningitis, including those with tuberculous meningitis who had received treatment with streptomycin for one month, had central deafness due to the disease or the drugs used in treatment.

Other Cases-14 Cases. Fourteen other children were referred either because of apparent deafness, speech difficulties or general retardation. These children were aged between 3 and 8 years (Table 4).

This group appears to be the most interesting and most important when deafness or speech disturbance was suspected either by parent, teacher or doctor. Investigation of these cases seems more likely to reveal the cause of trouble. Thus, out of 14 children so referred, five had conductive deafness associated with otorrhoea, one had severe deafness, three were mentally defective and five were quite normal.

Local Authority Register of Deaf Children. An attempt to study the problem in another way was made by finding out from the Local County Borough Authorities and the two Local Health
TABLE 5

COUNTY Boroughs A AND B

\begin{tabular}{|c|c|c|c|c|c|c|c|c|}
\hline \multirow{2}{*}{$\begin{array}{c}\text { Age } \\
\text { (years) }\end{array}$} & \multicolumn{2}{|c|}{ Deaf } & \multicolumn{2}{|c|}{$\begin{array}{c}\text { Partially } \\
\text { Deaf }\end{array}$} & \multicolumn{2}{|c|}{ Meningitis } & \multicolumn{2}{|c|}{ Prematurity } \\
\hline & $\mathbf{A}$ & B & $\mathbf{A}$ & B & $\mathbf{A}$ & B & $\mathbf{A}$ & B \\
\hline $\begin{array}{l}\text { Over } 5 \\
\text { Under } 5\end{array}$ & $\begin{array}{l}1 \\
0\end{array}$ & $\begin{array}{l}6 \\
3\end{array}$ & $\begin{array}{r}12 \\
2\end{array}$ & $\begin{array}{r}19 \\
0\end{array}$ & $\begin{array}{l}\mathbf{0} \\
\mathbf{0}\end{array}$ & $\begin{array}{l}0 \\
0\end{array}$ & $\begin{array}{l}\mathbf{0} \\
\mathbf{0}\end{array}$ & $\begin{array}{l}0 \\
1\end{array}$ \\
\hline
\end{tabular}

TABLE 6

Lancashire County Councils, A and B

\begin{tabular}{|c|c|c|c|c|c|c|}
\hline \multirow{2}{*}{$\underset{\text { (years) }}{\text { Age }}$} & \multicolumn{2}{|c|}{$\begin{array}{c}\text { Deaf and } \\
\text { Partially Deaf }\end{array}$} & \multicolumn{2}{|c|}{ Meningitis } & \multicolumn{2}{|c|}{ Prematurity } \\
\hline & $\mathbf{A}$ & B & $\mathbf{A}$ & B & $\mathbf{A}$ & B \\
\hline $\begin{array}{l}\text { Over } 5 \\
\text { Under } 5\end{array}$ & $\begin{array}{r}17 \\
0\end{array}$ & $\begin{array}{r}32 \\
0\end{array}$ & $\begin{array}{l}2 \\
0\end{array}$ & $\begin{array}{l}4 \\
0\end{array}$ & $\begin{array}{l}1 \\
0\end{array}$ & $\begin{array}{l}1 \\
0\end{array}$ \\
\hline
\end{tabular}

Divisions of the Lancashire County Council in the area, the number of deaf children on their registers and the manner in which deafness had arisen or been discovered. The results are shown in the accompanying Tables 5 and 6.

In the two County Borough areas, there was only one child in whom deafness was associated with prematurity. This child has already been mentioned in the section on premature infants and was born in 1957 with a birth weight of $1 \mathrm{lb} .15 \mathrm{oz} .(878 \mathrm{~g}$.) and was very slow to make progress.

In the two County Council areas, five children had deafness associated with acute meningitis and one following prolonged treatment for tuberculous meningitis. Three of these children had been treated in 1956, 1957 and 1958 respectively and the other two were much earlier cases, having been diagnosed and treated in 1948 and 1951 respectively. Two of these cases had been premature births in 1948 and 1953, when premature care in the area was almost non-existent.

All the other children with deafness listed in these two Tables have been ascertained following complaints by parent, teacher or doctor, because it was suspected that the child was either deaf or had chronic otorrhoea or was slow in speech or general mental development. Of course, some of the older children may have been victims of jaundice due to haemolytic disease in the days before the true significance of this condition was understood and before exchange transfusion was being practised. These cases are now being delivered in hospital and correct treatment should prevent this sort of trouble altogether in the future. 


\section{Discussion}

Prematurity. There is little doubt that some association occurs between deafness and prematurity. Corner (1960) in a follow-up study of 174 infants with a birth weight of under $3 \mathrm{lb} .4 \mathrm{oz}$. $(1,473 \mathrm{~g}$.) found three who were deaf, and had cerebral palsy; all these suffered from kernikterus or prematurity. Of five others with deafness alone, severe jaundice was a factor in two only. Other workers have found an association between deafness and prematurity varying between $17 \%$ (Gerrard, 1952) and $23 \%$ (Johnsen, 1952). An incidence of severe deafness in 1.7 out of every 1,000 premature infants who survived in the Northumberland and Durham area was reported by Barton, Court and Walker (1962).

In the present series, 88 babies in varying weight groups were tested and only one of them was found to be deaf. Difficulty was experienced in testing some of these infants at 9 months, as is recommended, for it was found that some of the smaller infants were unable to sit up unaided at this age and they had to be retested at 12-18 months.

Haemolytic Disease. The present understanding of the brain damage that neonatal jaundice can cause arises from the discovery of the rhesus factor and the later realization that neonatal jaundice and kernikterus can lead to the development of spasticity, athetosis and deafness. In 1948, papers began to appear noting the association of high-tone deafness with athetosis, and in 1954 Cavanagh drew attention to the reduction in incidence of perceptive deafness in a group of infants with haemolytic disease treated early by exchange transfusion compared with babies treated later in the illness or not at all. The degree of bilirubinaemia which may be regarded as absolutely safe is unknown but most centres nowadays try to prevent the level rising above $18-20 \mathrm{mg}$./ $100 \mathrm{ml}$. by exchange transfusion. However, Zuelzer and Brown (1961) reported one baby with a bilirubin of $54 \mathrm{mg} . / 100 \mathrm{ml}$. who developed normally, whereas Day (1961) quoted a case of kernikterus occurring in a baby whose bilirubin never rose above $12 \cdot 2 \mathrm{mg} . / 100 \mathrm{ml}$.
It appears from these studies and our own that the relation between bilirubinaemia and deafness is not a very clear one and other factors may well be involved.

Meningitis. The children who had meningitis, including those with tuberculous meningitis receiving streptomycin, had no central deafness due to the disease or to the drugs used.

\section{Conclusions}

It seems that the number of children ascertained as being deaf in the past five years is small and that prematurity, meningitis and haemolytic disease are not really playing any great part in the causation of the trouble.

The facts obtained from the survey of the cases of deafness known to the local authorities do not differ from the assessment made from the follow-up of cases treated in hospital.

As a result of this survey, it is wondered whether the time and trouble taken in the routine testing for deafness in infants who are usually regarded as being at risk is really worth while. It seems preferable to spend time testing children who show delay or difficulties with speech, those who have chronic otorrhoea and those who show slowness in mental progress, for amongst these groups one is more likely to find deaf children.

My thanks are due to the Paediatric Registrars and nursing staff who helped with these Clinics and to the Local Medical Officers who supplied the information about the deaf register.

\section{REFERENCES}

Barton, M. E., Court, S. D. and Walker, W. (1962). Causes of severe deafness in schoolchildren in Northumberland and Durham. Brit. med. J., 1, 351.

Cavanagh, F. (1954). The rhesus factor in deafness. J. Laryng., $68,444$.

Corner, B. (1960). Prematurity, p. 504. Cassell, London.

Day, R. L. (1961). Physiologic jaundice. Pediat. Clin. N. Amer., 8, 539 . Gerrard, J. (1952). Nuclear jaundice and deafness. J. Laryng.,

Johnsen, S. (1952). Natal causes of perceptive deafness. Acta oto-laryng. (Stockh.), 42, 51.

Zuelzer, W. W. and Brown, A. K. (1961). Neonatal jaundice: A review. Amer. J. Dis. Child., 101, 87. 